\title{
EFFECT OF TOOL GEOMETRY AND WELDING PARAMETERS ON THE MICROSTRUCTURE AND STATIC STRENGTH OF THE FRICTION-STIR SPOT-WELDED DP780 DUAL-PHASE STEEL SHEETS
}

\author{
VPLIV GEOMETRIJE ORODJA IN PARAMETROV VARJENJA NA \\ MIKROSTRUKTURO IN STATIČNO TRDNOST TORNO VRTILNEGA \\ TOČKOVNEGA VARJENJA DVOFAZNE JEKLENE PLOČEVINE DP780
}

\author{
Omid Abedini, Eslam Ranjbarnodeh, Pirooz Marashi \\ Amirkabir University of Technology, Department of Mining and Metallurgical Engineering, 424 Hafez Ave., Tehran, Iran \\ islam_ranjbar@aut.ac.ir
}

Prejem rokopisa - received: 2016-09-03; sprejem za objavo - accepted for publication: 2016-09-27

doi:10.17222/mit.2016.278

\begin{abstract}
In this study, friction-stir spot welding is performed on DP780 dual-phase steel sheets to investigate the effect of the tool geometry and welding parameters on the static strength, the failure mode and the microstructure of the welds. First, the effects of two different parameters, the tool plunge depth and the tool holding time, were evaluated, where the tool penetration varied between $1.9-2.8 \mathrm{~mm}$ and the dwell time between $8-16 \mathrm{~s}$. The tensile shear strength was first increased with the tool penetration and then decreased, while a longer tool holding time increased the tensile shear strength of the joints. Next, welds were made to compare the effects of two tool geometries, i.e., the conventional tapered pin and the triangular pin, on the hook shape, microstructure and static strength. The difference in the hook geometry led to differences in the tensile shear strength of the welds. The static strength of the welds made with the triangular pin was higher than that obtained using the tapered pin.

Keywords: friction-stir spot welding, tool geometry, static strength, dual-phase steel, microstructure
\end{abstract}

V študiji je izvedeno torno vrtilno točkovno varjenje na DP780 dvofazni jekleni pločevini, z namenom raziskave vpliva geometrije orodja in varilnih parametrov na statično trdnost, tip poškodbe in mikrostrukturo zvarov. Najprej so bili ocenjeni učinki dveh različnih parametrov, globine penetriranja in časa zadržanja orodja. Globina je variirala med $1,9 \mathrm{~mm}$ in $2,8 \mathrm{~mm}$ in zadrževalni čas med $8 \mathrm{~s}$ in $16 \mathrm{~s}$. Natezna strižna trdnost se je s povečanjem globine penetracije najprej zvišala, nato pa znižala, medtem ko je čas zadrževanja orodja povečal natezno strižno trdnost zvarov. Izdelani so bili tudi zvari, na katerih se je določil vpliv geometrije orodja, klasičnega polkrožnega in trikotnega profila, na obliko, mikrostrukturo in trdnost zvarov. Statična trdnost zvarov, narejenih z orodjem trikotnega profila, je bila višja kot tista, pridobljena s polkrožno obliko.

Ključne besede: torno-vrtilno točkovno varjenje, geometrija orodja, statična trdnost, dvofazno jeklo, mikrostruktura

\section{INTRODUCTION}

Friction-stir welding (FSW) is a new solid-state joining technique, developed by TWI in 1991. This new welding method is usually used in the welding of plates and is different from conventional friction welding. ${ }^{1}$ Friction-stir welding is commercially used for the welding of light metals such as aluminium alloys, e.g., standard-length $\mathrm{Al}$ extrusion panels for high-speed cruise ships, fuel tanks used in aerospace manufacturing and carriage manufacturing of high-speed trains. ${ }^{2-4}$ Friction-stir spot welding (FSSW) is a derivative of friction-stir welding and is widely used for the welding of soft metals such as $\mathrm{Al}-, \mathrm{Cu}-$ and $\mathrm{Mg}$-alloys as well as different material combinations, particularly those with close melting temperatures. As a new solid-state joining process, FSSW, can avoid many problems associated with the fusion-welding processes. Therefore, in recent years, its applications have been extended to the welding of high-melting-temperature materials such as various types of steels, nickel and titanium alloys. ${ }^{1-7}$ Following the success in the friction-stir spot welding of several steel alloys including hot-stamped boron steel, ${ }^{8}$ DP600 and M190, ${ }^{9}$ attempts to evaluate this process for the welding of more problematic steel alloys took place.

Dual-phase (DP) steels are an important class of high-strength low-alloy steels (HSLA) that have a unique combination of properties such as high tensile strength, high elongation, high ratio of strength to weight and continuous yielding. These properties stem from the microstructure of dual-phase steels, in which a soft and ductile matrix of ferrite provides good ductility while hard martensite islands provide high strength. ${ }^{9-11}$ In the case of dual-phase steels, fusion-welding technique, such as resistance spot welding, are inadequate due to a dramatic softening in the heat-affected zone. ${ }^{12}$ Therefore, the application of solid-state welding processes, such as friction-stir spot welding, for joining these steels has been extended. ${ }^{3}$ Although the feasibility of joining advanced high-strength steels (AHSS) with friction-stir spot welding has been recently considered, it is shown that microstructural changes during FSSW dramatically affect mechanical properties by transforming the base-metal (BM) microstructure..$^{13}$ To date, the microstructures and failure 
mechanisms of friction-stir spot-welded DP780 have not been examined in great detail. Thus, the increased utilization of advanced high-strength steel grades in the automotive architecture emphasized the need to examine how the FSSW joining works.

During friction-stir spot welding, a non-consumable rotating tool consisting of a pin and a shoulder is inserted into the upper sheet of a lap configuration while the backing tool beneath the lower sheet supports the downward force. Important process parameters of FSSW are the tool geometry, plunge depth, rotational speed, plunge rate, tilt angle and holding time. The tool plunge depth and the holding time determine the amount of heat generation, the material flow into the overlapped sheets, the weld geometry and, therefore, the mechanical properties of joints. ${ }^{13-18}$

It is reported ${ }^{17}$ that the tool plunge depth strongly affects the strength of friction-stir spot-welded joints. However, it is shown that a deep tool penetration decreases the joint volume and the upper sheet thickness which, in turn, decreases the tensile shear strength. ${ }^{14,15}$ The friction-stir spot welding of lap-configuration sheets is characterized by the formation of a partial metallurgical bond called the hook. The hook is a geometrical defect, formed in the weld region between the joining sheets. There is often a thin oxide film on the surface of the metallic materials. During the tool penetration into the bottom sheet, the oxide film is broken up into smaller particles. Distribution of the small oxide particles, because of the stirring of the tool, leads to the formation of the metallurgical bond between the two welded sheets. The tool-pin design significantly affects the hook geometry; thus, the failure mode and the static strength of the welds are influenced. ${ }^{16,19-22}$

Many efforts have been made to optimize the welding parameters and the tool design as well as modifying the friction-stir spot welding technique using a tool without a probe. ${ }^{23,24}$ However, further investigation on the effect of the welding parameters and tool-pin geometry on the

(a)
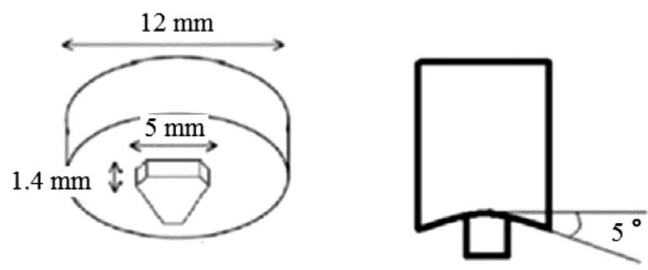

(b)
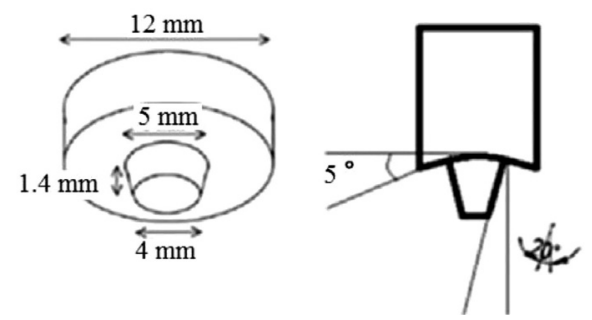

Figure 1: Schematic illustration of FSSW tool geometry: a) triangular pin shape, b) tapered pin shape properties of the joints is required. Therefore, this study applies friction-stir spot welding to DP780 dual-phase steel sheets using a WC-Co alloy tool with two, taperedand triangular-pin, geometries and a concave shoulder design with the following two goals. The first is to investigate the influence of the tool penetration depth and tool holding time on the mechanical shear strength and microstructure of the welded joints. The penetration depth and tool holding time were chosen because these two parameters have significant effects on the joint properties. The second goal of this work is to analyse the effect of the pin design on the hook geometry, weld strength and failure mode.

\section{EXPERIMENTAL PART}

1.5-mm-thick DP780 sheets were used in this study as the base metal whose chemical composition is summarized in Table 1. Individual sheet dimensions were $140 \mathrm{~mm} \times 60 \mathrm{~mm}$ and the sheets were joined in the lap position with an overlap area of $45 \mathrm{~mm} \times 60 \mathrm{~mm}$. The friction-stir spot welding equipment provided rotational speeds from $1000 \mathrm{~min}^{-1}$ to $2500 \mathrm{~min}^{-1}$ and axial loads of up to $30 \mathrm{kN}$. The FSSW tools were made from the WC-Co alloy having a pin length of $1.4 \mathrm{~mm}$ and a shoulder with a diameter of $12 \mathrm{~mm}$ with a concave profile. As schematically shown in Figure 1, two different pin geometries were used: the tapered and triangular ones. All spot welds were made under the following processing conditions: the tool rotational speed and the plunge rate were kept constant at $1000 \mathrm{~min}^{-1}$ and 20 $\mathrm{mm} / \mathrm{min}$, respectively, while the tool holding time was $(8,12$ or 16$) \mathrm{s}$ and the tool plunge depth was $(1.9,2.2$, 2.5 or 2.8$) \mathrm{mm}$.

Table 1: Material properties of DP780 (in mass fractions, w/\%)

\begin{tabular}{|c|c|c|c|c|c|c|c|}
\hline Element & $\mathrm{C}$ & $\mathrm{Mn}$ & $\mathrm{Si}$ & $\mathrm{Ni}$ & $\mathrm{Cr}$ & $\mathrm{S}$ & $\mathrm{p}$ \\
\hline Content & 0.1 & 0.44 & 0.13 & 0.04 & 0.08 & 0.02 & 0.14 \\
\hline
\end{tabular}

Joint mechanical properties of the spot welds were evaluated with the hardness profile and tensile shear tests. A Vickers microhardness measurement was conducted at $0.3 \mathrm{~mm}$ above the interface of the overlapped sheets on the metallographic samples under a load of $500 \mathrm{~g}$ for $15 \mathrm{~s}$. The tensile shear test was performed using an Instron 8502 machine with a constant crosshead speed of $1 \mathrm{~mm} / \mathrm{min}$. The lap shear strength was obtained by averaging the strength of five individual samples, welded using identical welding parameters. Macro- and micro-structure examinations were performed on the specimens. As-welded and tested samples were sectioned along the diameter of the weld keyhole. Metallographic observations were made with a light microscope and a scanning electron microscope (SEM, Hitachi S-2400) following the standard metallographic polishing and etching with a $2 \%$ nital solution. 
O. ABEDINI et al.: EFFECT OF TOOL GEOMETRY AND WELDING PARAMETERS ON THE MICROSTRUCTURE ..

\section{RESULTS AND DISCUSSION}

\subsection{Tensile shear strength}

3.1.1 Effect of welding parameters on the tensile shear strength

The relationships between the tensile shear force $\left(F_{\mathrm{s}}\right)$, tool holding time $(t)$ and plunge depth for both the triangular and tapered pin, for a constant $1000 \mathrm{~min}^{-1}$ tool rotational speed and a $20 \mathrm{~mm} / \mathrm{min}$ tool plunge rate are indicated for individual data points in Figure 2. It is shown that the tensile shear force reaches its maximum at the $2.2 \mathrm{~mm}$ plunge depth and $16 \mathrm{~s}$ tool holding time. Thus, for both the plunge depth and the tool holding time, the tensile-shear-force trend was independent of the tool geometry.

Figures 3a and $\mathbf{3 b}$ show examples of the size of the stir zone for the welding conditions consisting of the tool rotational speed of $1000 \mathrm{~min}^{-1}$, tool plunge rate of $20 \mathrm{~mm} / \mathrm{min}$, tool holding time of $16 \mathrm{~s}$ and plunge depth of $1.9 \mathrm{~mm}$ and $2.2 \mathrm{~mm}$, respectively, using the triangular pin. It can be seen that for the $2.2 \mathrm{~mm}$ tool plunge depth, the amount of the upward material flow of the lower sheet is higher than that of the weld with the $1.9 \mathrm{~mm}$ tool plunge depth. An increase in the upward material flow increases the faying surface between the upper and lower sheets, which, in turn, increases the tensile shear strength..$^{25-26}$

Figure 4 shows views of macrosections taken at different plunge depths of $(2.2,2.5$ and 2.8$) \mathrm{mm}$ at a constant $1000 \mathrm{~min}^{-1}$ tool rotational speed and 20

\section{(a) Rotational speed 1000 rpm - Triangular}

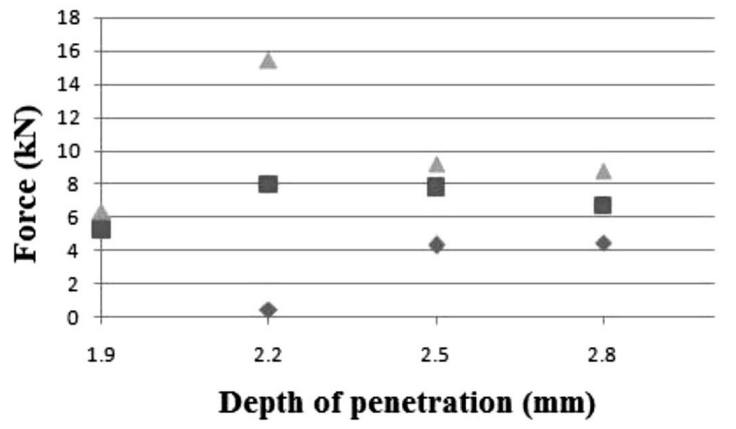

(b) Rotational speed 1000 rpm - Tapered

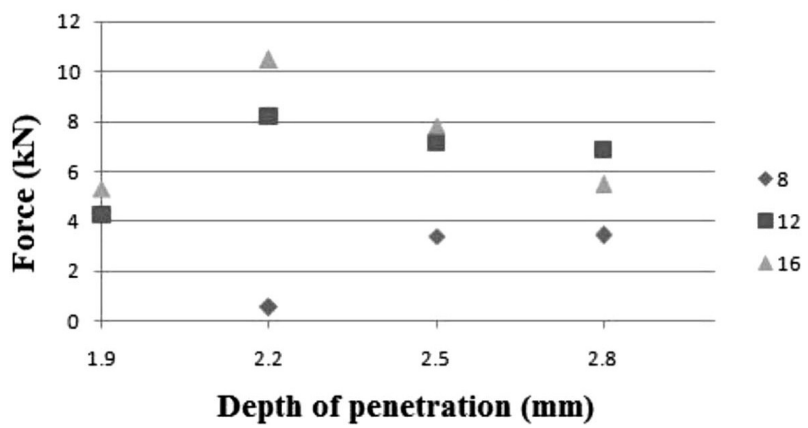

Figure 2: Tensile-shear force as a function of plunge depth and tool holding time at $1000 \mathrm{~min}^{-1}$ rotational speed for two different tool designs: a) triangular pin, b) tapered pin
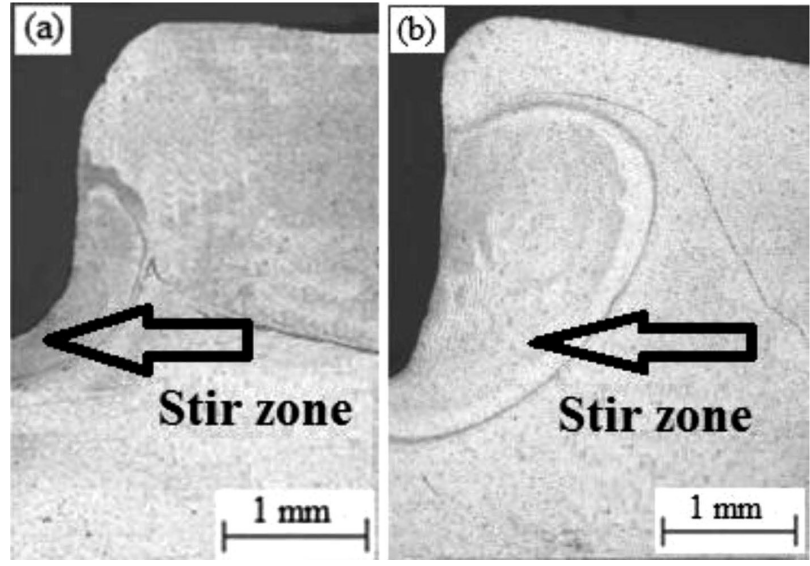

Figure 3: Microstructures of the stir zones of friction-stir spot welds for: a) $1.9 \mathrm{~mm}$ plunge depth and b) $2.2 \mathrm{~mm}$ plunge depth at a tool rotational speed of $1000 \mathrm{~min}^{-1}$ and dwell time of $12 \mathrm{~s}$ for the triangular pin
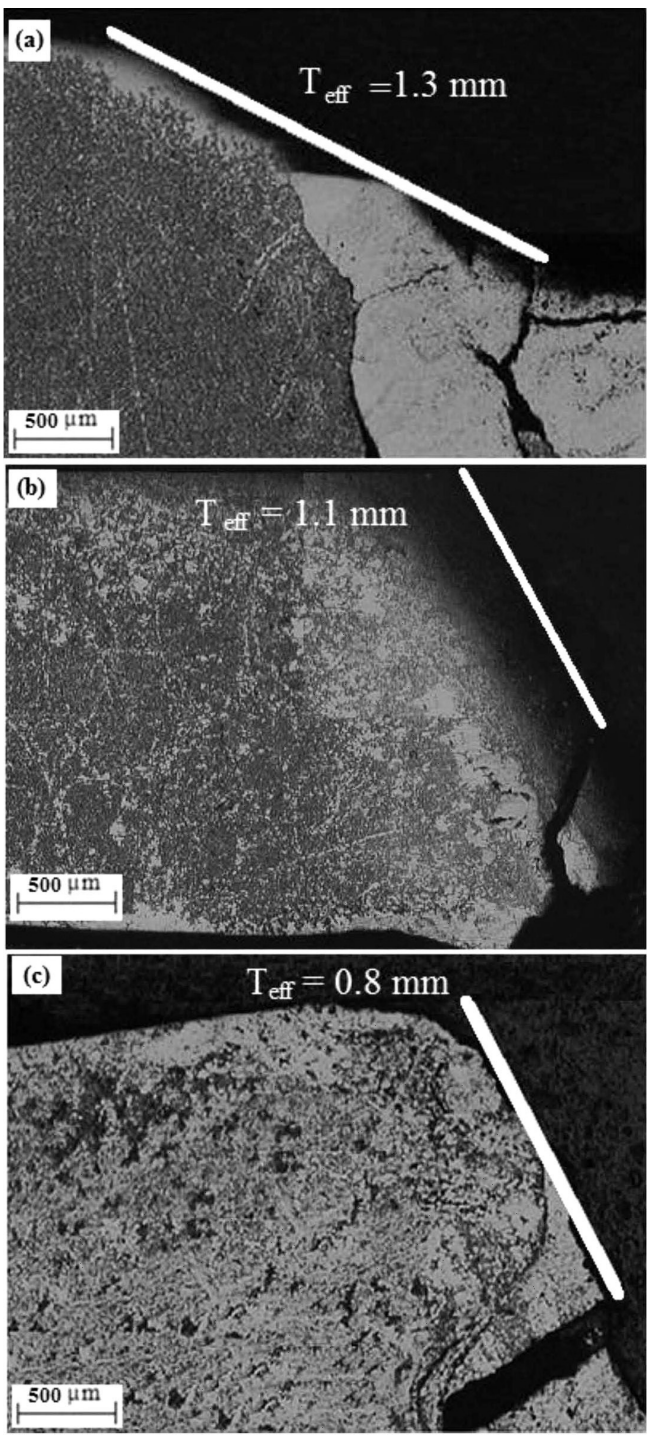

Figure 4: Typical cross-sectional macrostructures of friction-stir spot welds (a holding time of $16 \mathrm{~s}$ using a triangular pin) showing different upper-sheet thickness values: a) FSSW at $2.2 \mathrm{~mm}$, b) FSSW at $2.5 \mathrm{~mm}$ and c) FSSW at $2.8 \mathrm{~mm}$ 
O. ABEDINI et al.: EFFECT OF TOOL GEOMETRY AND WELDING PARAMETERS ON THE MICROSTRUCTURE ...

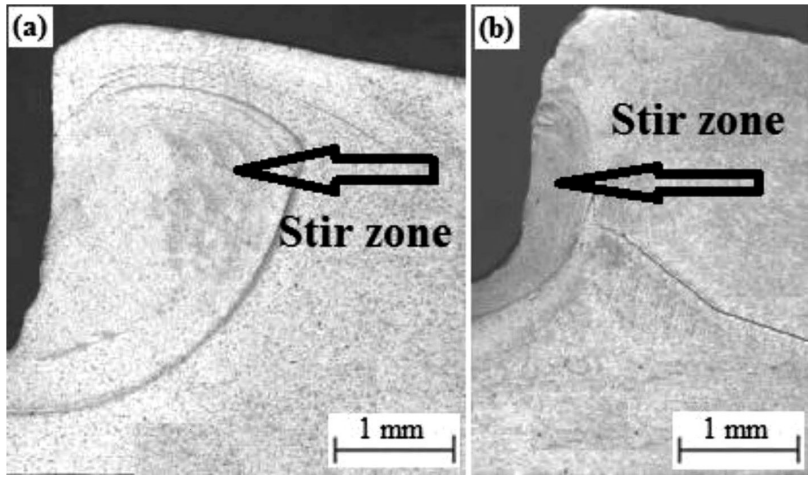

Figure 5: Typical cross-sectional macrostructures of friction-stir spot welds made with a triangular pin: a) plunge depth of $2.2 \mathrm{~mm}$ and tool holding time of $16 \mathrm{~s}$, b) plunge depth of $2.2 \mathrm{~mm}$ and tool holding time of $8 \mathrm{~s}$; rotational speed for both welds is $1000 \mathrm{~min}^{-1}$

$\mathrm{mm} / \mathrm{min}$ tool plunge rate, using the triangular pin. It is shown that an increasing tool plunge depth decreases the thickness of the upper sheet, which, in turn, decreases the tensile shear force of the welds made with the triangular pin from $15.46 \mathrm{kN}$ to $8.81 \mathrm{kN}$. In fact, the thickness of the upper sheet is a function of the tool penetration depth; thus, a deep plunge depth can decrease the weld strength because the thickness of the upper sheet decreases with the increase in the plunge depth. ${ }^{25,27}$ As can be seen in Figure 4, the final crack path in the fractured samples is through the effective thickness of the upper sheet. As a result, the thickness of the upper sheet provides resistance against external loading; therefore, to obtain a weld with high static strength, the thickness of the upper sheet should be as large as possible. According to the above reasons, the weld made with the $2.2 \mathrm{~mm}$ tool penetration depth has the highest tensile shear force for both the triangular and tapered pin.

Figure 2 also reveals that at the constant tool plunge depth of $2.2 \mathrm{~mm}$, the increase in the tool holding time from $8 \mathrm{~s}$ up to $16 \mathrm{~s}$ increases the tensile shear force of the welds from $0.54 \mathrm{kN}$ to $10.49 \mathrm{kN}$ and from $0.42 \mathrm{kN}$ to $15.46 \mathrm{kN}$ for the tapered and triangular pin, respectively. In fact, by increasing the tool holding time at a constant plunge depth, the upward material flow of the lower sheet increases, which, in turn, increases the size of the stir zone, thus increasing the tensile shear force. ${ }^{19}$ From Figure 5, it is evident that at the constant tool plunge depth of $2.2 \mathrm{~mm}$, the longer tool holding time results in a larger stir zone. As a result, the tensile shear strength of a joint is maximum at the $16 \mathrm{~s} \mathrm{dwell} \mathrm{time} \mathrm{and} \mathrm{the} \mathrm{constant}$ tool penetration depth.

\subsubsection{Effect of the tool geometry on the tensile shear strength}

Figure 2 shows that the maximum strength of the weld made with the triangular pin at the $2.2 \mathrm{~mm}$ plunge depth and $16 \mathrm{~s}$ tool holding time is about $50 \%$ higher than that of the weld made with the tapered one at the same conditions. The existence of this difference between the tensile shear forces is due to the manner of the
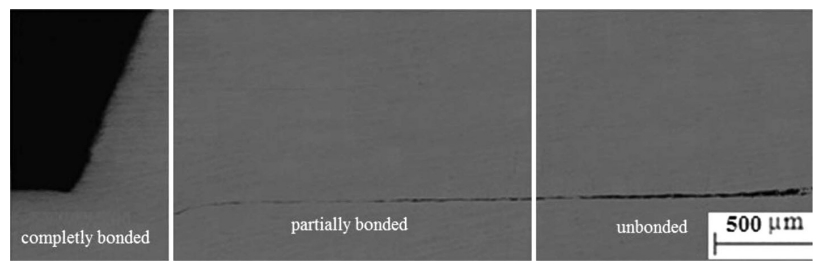

Figure 6: Macrostructure of a friction stir spot welds. Three characteristic regions: completely bonded region, partially bonded region and unbonded region

upward material flow during friction-stir spot welding using two different pin designs. ${ }^{16,28}$ As it can be seen in the cross-sectional microstructure in Figure 6, there are three characteristic regions: a completely bonded region, a partially bonded region and an unbounded region, which are in sequence from the weld keyhole towards the base metal. These regions were fully described elsewhere. ${ }^{16}$ As mentioned above, the hook is a partially metallurgically bonded area, which forms in the weld region between the welded sheets.

Figure 7 shows the pattern of the material flow and the formation of the hook in the weld region during friction-stir spot welding using tapered and triangular pins. As reported by $\mathrm{H}$. Badarinarayan et al., ${ }^{16}$ the geometry of the pin significantly affects the hook geometry. In the case of the weld made with the tapered pin, the hook moves upward and then, near the stir-zone points, downward toward the weld bottom. When using this special shape of tool, the symmetrical rotation of the pin causes a shear deformation of the material around the pin surface. On the other hand, the hook direction in the weld
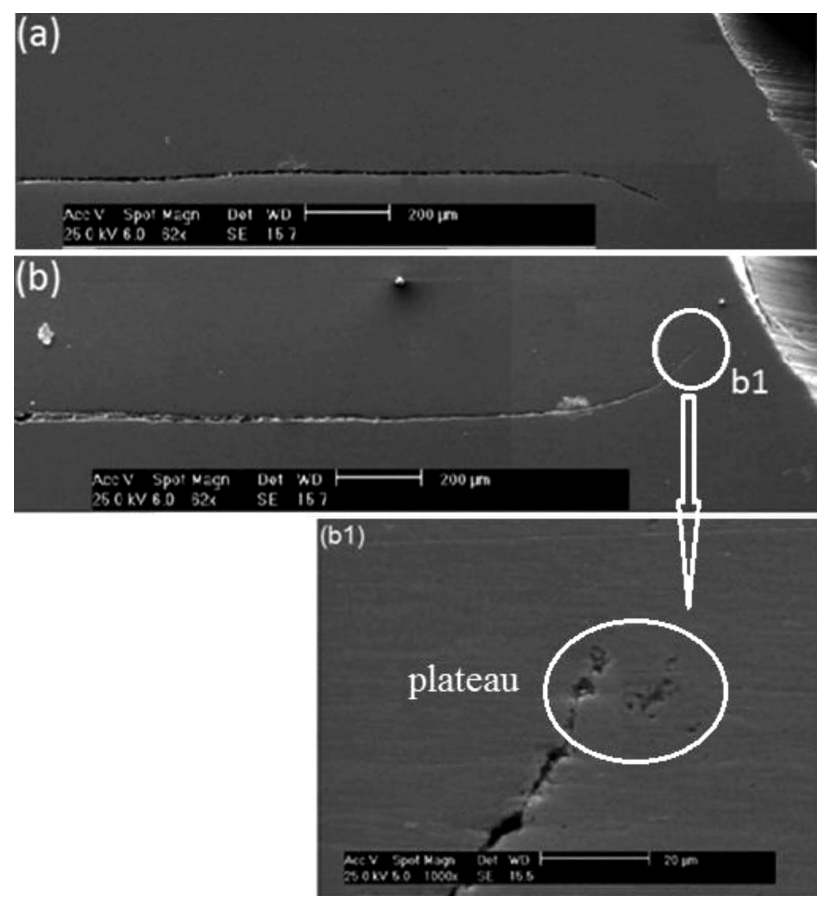

Figure 7: Views of the hook geometry of the welds made with: a) tapered pin, b) triangular pin; b1) magnified view of the plateau at the end of the hook in region b1 for the friction-stir spot weld made with the triangular pin 


\section{O. ABEDINI et al.: EFFECT OF TOOL GEOMETRY AND WELDING PARAMETERS ON THE MICROSTRUCTURE}
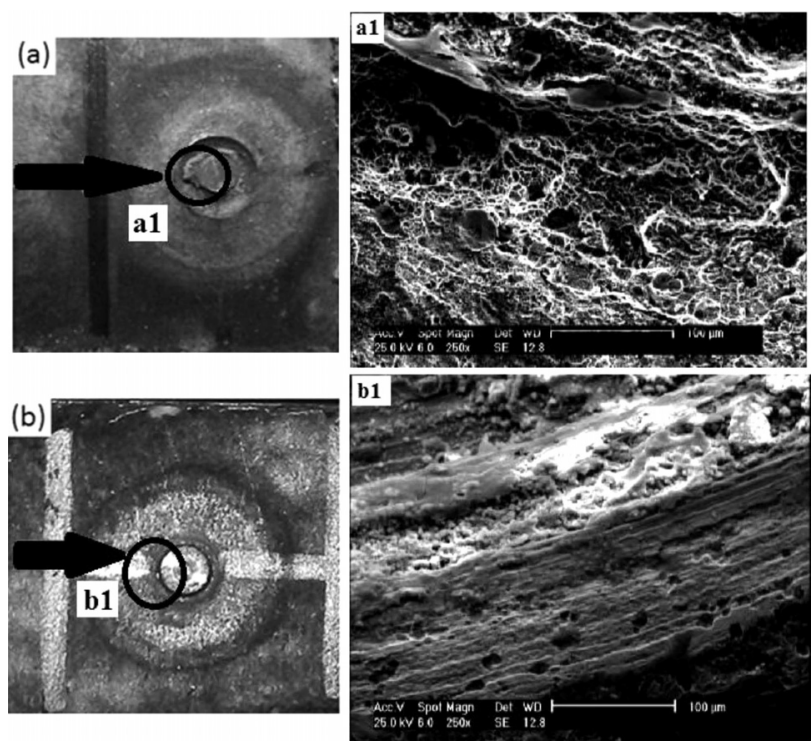

Figure 8: a) Appearance of the weld made with tapered pin after fracture, b) appearance of the weld made with triangular pin after fracture; a1) fractograph of selected location a1 on the friction-stir spot weld made with tapered pin, b1) fractograph of selected location b1 on the friction-stir spot weld made with triangular pin

made with the triangular pin is upward towards the stir zone and ends with a plateau, as can be seen in Figure 7b. The large difference in the shear tension strength between the welds made with the two different types of pin could be caused by the following factors: the finer-grain structure near the weld keyhole, the strength of the material in this region that is higher than that near the weld bottom. On the other hand, the crack propagation happens along the hook in both welds; on the weld made with the tapered pin, the crack initially passes around the stir zone and then moves down towards the weld bottom while on the weld made with the triangular pin, the crack moves upward towards the stir zone along the hook. For this reason, the failure load of the weld made with the triangular pin is about $50 \%$ higher than that of the weld made with the tapered one at the same processing conditions (2.2 $\mathrm{mm}$ plunge depth, $16 \mathrm{~s}$ tool holding time) used in this study.

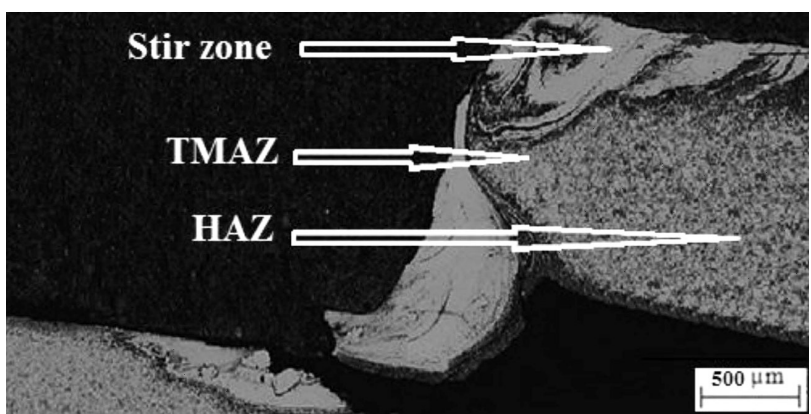

Figure 9: Cross-sectional microstructure of a friction-stir spot weld (the plunge depth of $2.2 \mathrm{~mm}$ and dwell time of $16 \mathrm{~s}$ ) showing different regions of the weld: stir zone (SZ), heat-affected zone (HAZ), thermo-mechanically affected zone (TMAZ)
On the contrary, the fracture surface in Figure 8 shows that the failure mode varies for the welds made with two different pin designs when they are subjected to shear-tension loading. The existence of dimples in the fracture surface of the weld made with the tapered pin shows that, during the final stage of failure, this weld experiences a plastic collapse near the weld bottom in the shear mode while, in the weld made with the triangular pin, fracture occurs due to the crack propagation through the stir zone under the tension. Therefore, a higher external load causing the failure of the weld made with the triangular pin might be related to the tensile failure mode where the tensile strength of the material is about 1.6 times the shear strength.

\subsection{Microstructure characterization of the welds}

The cross-sectional microstructure of the friction-stir spot weld in Figure 9 shows that the microstructure of the weld consists of three distinct zones: the dynamically recrystallized zone or stir zone (SZ), which lies at the centre of the spot weld, bordering, on either side, on the remaining two constituent zones, the thermo-mechanically affected zone (TMAZ) and the heat-affected zone (HAZ). The microstructure of the stir zone includes very fine grains subjected to a high strain and also high thermal energies from the rotational pin. Due to the occurrence of phase transformation in this region, the micro-
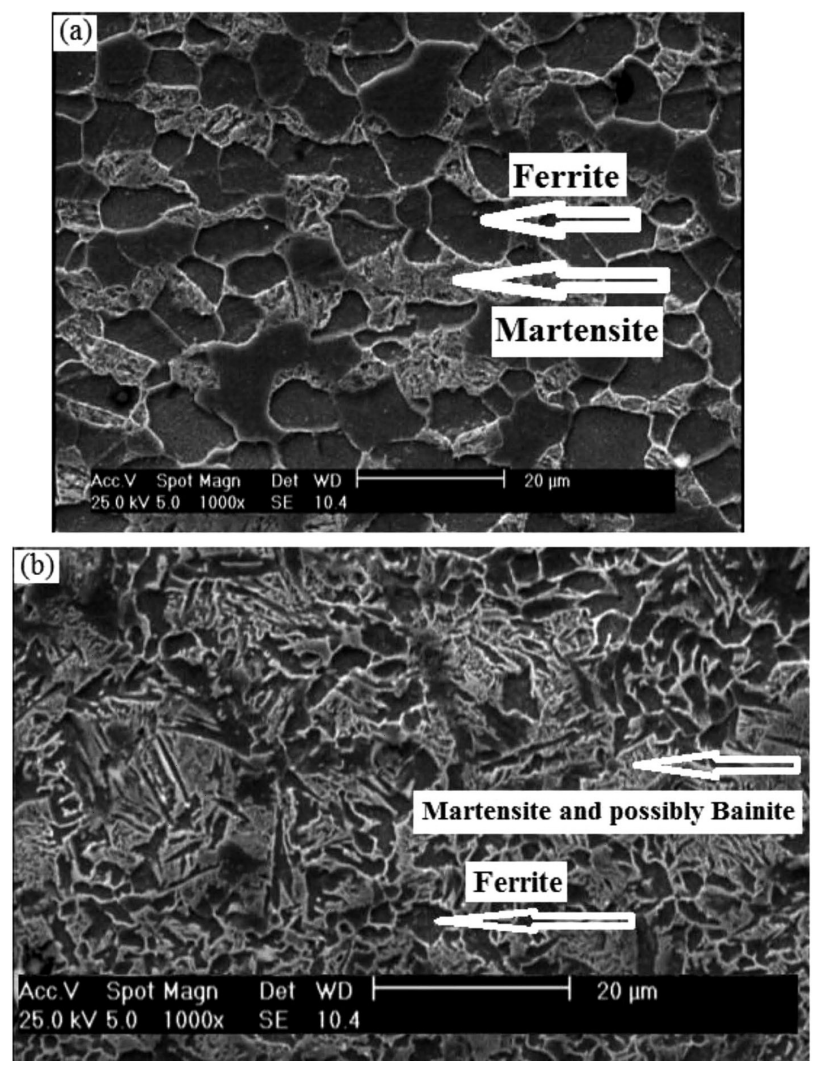

Figure 10: SEM micrographs of cross-sectional microstructures of a friction-stir spot weld (the plunge depth of $2.2 \mathrm{~mm}$ and dwell time of $16 \mathrm{~s}$ ): a) base material, b) heat-affected zone (HAZ) 
structure morphology of the stir zone is quite different from those of the other regions. ${ }^{4,14}$ The thermo-mechanically affected zone (TMAZ), which is entirely unique to FSSW, is affected by both the deformation and the temperature during friction-stir spot welding. This region is the transition zone between the parent material and the nugget zone. The grains in the TMAZ are highly elongated due to high strain forces and the presence of an upward-flowing pattern around the stir zone. ${ }^{14,29}$ Furthermore, the thermo-mechanically affected zone is the heat-affected zone (HAZ) that is not plastically deformed but undergoes a thermal cycle during the friction-stir welding process. ${ }^{29}$

A SEM micrograph of the DP780 steel as the base metal is shown in Figure 10a. It shows that the micro-
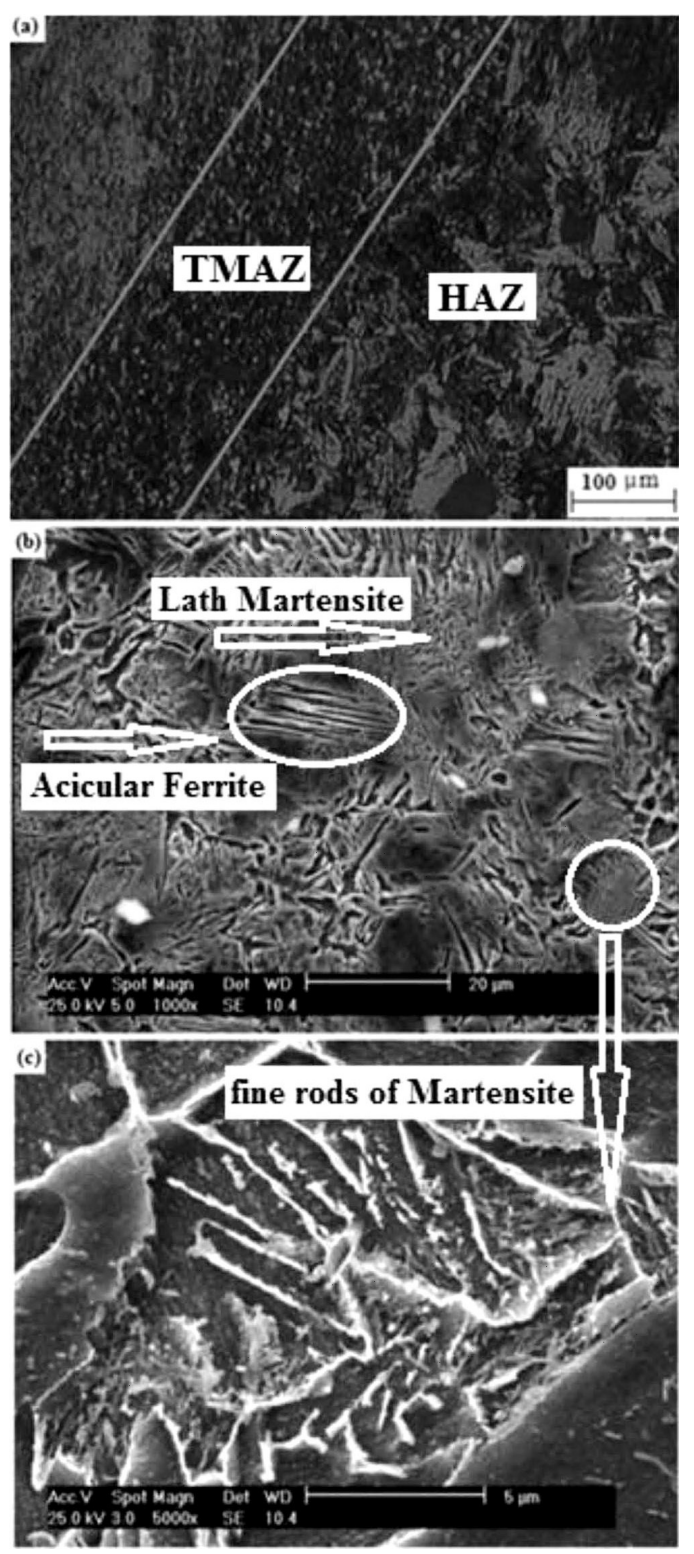

Figure 11: a) optical microscopy of the microstructure of the HAZ and TMAZ in friction-stir spot weld, b) scanning electron microscopy of the microstructure of the TMAZ in friction-stir spot weld (the plunge depth of $2.2 \mathrm{~mm}$ and dwell time of $16 \mathrm{~s}$ ) structure of the base metal is composed of martensite islands surrounded by a ferrite matrix. The hardness values of the base metal are in the range of 190-210 HV0.15, which can be an indication of the mainly ferritic nature of the base-metal microstructure. As can be seen in Figure 10b, the original grains in the HAZ are homogeneously distributed, and the microstructure of the HAZ consists of tempered martensite and possibly bainite along with some pre-existing martensite in the ferrite matrix. The peak temperature in the heat-affected zone (HAZ) is between the martensite tempering temperature and the liquidus. Coarsening of the martensite phase occurs in this region where the peak temperature is between $A C_{1}$ and $A C_{3}$. Increasing the temperature above $A C_{3}$ results in a complete austenitization, which, in turn, leads to the formation of fine ferrite grains and the banding nature of martensite and possibly bainite. ${ }^{1}$ According to the above reason, the grain size and the volume fraction of the martensite in the heat-affected zone (HAZ) are increased. The hardness values in this region (250-270 HV0.15) indicate an increase in the martensite volume fraction in the microstructure.

Figure 11 shows the cross-sectional microstructures of the heat-affected zone and thermo-mechanically affected zone. As it is shown, the grains in the HAZ tend to grow because of the significant amount of the heat generated during friction-stir spot welding. However, the fine-grained microstructure in the thermo-mechanically affected zone is due to the continuous dynamic recrystallization, induced by shear deformation and a high amount of the heat generated during welding. ${ }^{1}$ The temperature of the TMAZ goes above $\mathrm{AC}_{3}$ and this region undergoes a high strain leading to dynamic recrystallization. ${ }^{12}$ As a result, the microstructure of the TMAZ is composed of a mixture of lath martensite and fine acicular ferrite (Figure 11b). In addition to the lath martensite, fine rods of martensite, which are less than $2 \mu \mathrm{m}$ long, are observed in the microstructure. The average hardness in the TMAZ is about $310 \mathrm{HV} 0.15$.

As mentioned above, the microstructure of the stir zone includes very fine grains and the morphology of this region is quite different from those of the other regions. ${ }^{14}$ Figure 12 shows a finer-grain microstructure of

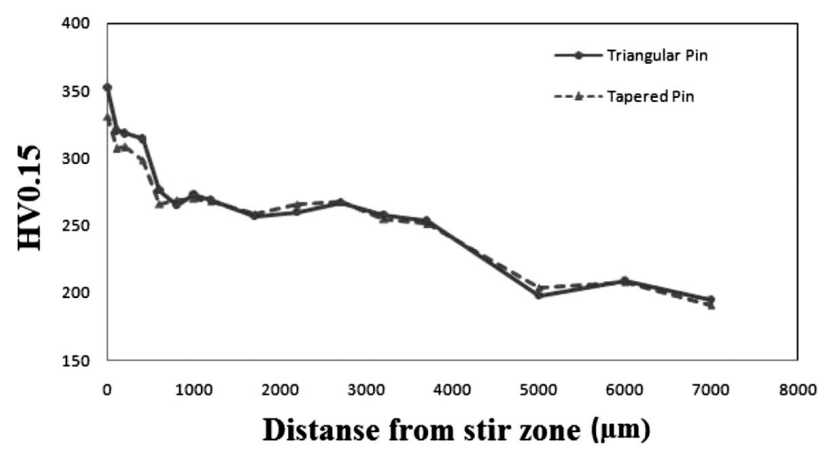

Figure 12: SEM images of the microstructure of the stir zone in a friction-stir spot weld (the plunge depth of $2.2 \mathrm{~mm}$ and dwell time of 16 s) and a magnified view of the martensitic microstructure in this region 
O. ABEDINI et al.: EFFECT OF TOOL GEOMETRY AND WELDING PARAMETERS ON THE MICROSTRUCTURE ...

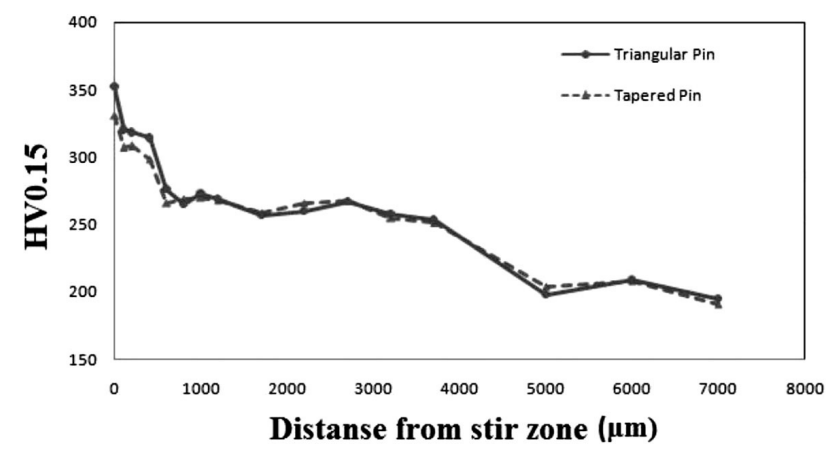

Figure 13: Microhardness profile for friction-stir spot welding using triangular and tapered pins

the stir zone of a friction-stir spot weld as compared to the other regions. As indicated in this figure and according to the high hardness values of the microhardness profile on Figure 13, the microstructure of the stir zone predominately consists of martensite.

\subsection{Microhardness profiles}

A microhardness profile is an excellent indicator of the changes in the properties occurring across the weld zone. ${ }^{30}$ Figure 13 shows the microhardness plot of different regions around the stir zone for the welds performed with the triangular and tapered pins. As can be seen in this figure, the stir zone and thermo-mechanically affected zone of the weld made with the triangular pin is, on average, a little harder than the weld made with the tapered one. SEM micrographs of the thermo-mechanically affected zone on Figure $\mathbf{1 4}$ shows that the plastic deformation during the friction-stir spot welding using the triangular pin is more severe than that of the tapered pin; therefore, the grain size of the TMAZ in the weld made with the triangular pin is finer than that of the weld made with the tapered one. The mechanism of the material flow during the FSSW using different tool designs was fully described elsewhere. ${ }^{16,31}$ As a result, the finergrain structure in the stir zone and thermo-mechanically affected zone of the FSSW using the triangular pin led to a higher hardness than that of the weld made with the tapered pin.

\section{CONCLUSIONS}

1. The weld made with the $2.2 \mathrm{~mm}$ tool penetration depth has the highest tensile shear force. In fact, the amount of the upward material flow of the lower sheet is increased with the plunge depth, regardless of the tool holding time. Thus, the tensile shear strength is first increased with the plunge depth of up to $2.2 \mathrm{~mm}$ and then it starts to decrease with a further increase in the plunge depth to $2.8 \mathrm{~mm}$.

2. At the constant tool plunge depth of $2.2 \mathrm{~mm}$, by increasing the tool holding time from $8 \mathrm{~s}$ up to $16 \mathrm{~s}$, the tensile shear force of the welds is increased from

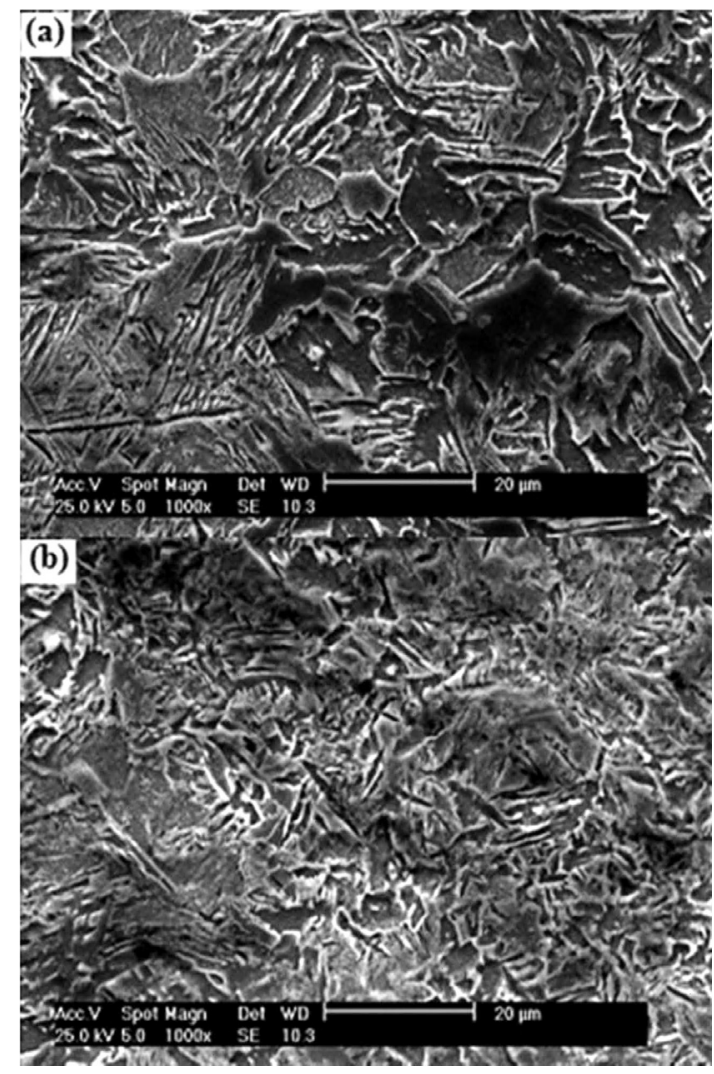

Figure 14: SEM micrographs of the microstructure of the TMAZ for friction-stir spot welds (the plunge depth of $2.2 \mathrm{~mm}$ and dwell time of $16 \mathrm{~s})$ with two different tool geometries: a) tapered pin, b) triangular pin

$0.54 \mathrm{kN}$ to $10.49 \mathrm{kN}$ and from $0.42 \mathrm{kN}$ to $15.46 \mathrm{kN}$ for the tapered and triangular pin, respectively.

3. For the weld made with a tapered pin, the crack initially passes around the stir zone and then moves down towards the weld bottom, while, for the weld made with a triangular pin, the crack moves upward towards the stir zone along the hook. Because of the finer-grain structure near the weld keyhole, the material is stronger in this region than near the weld bottom. Therefore, the maximum strength of the weld made with the triangular pin at the $2.2 \mathrm{~mm}$ plunge depth and $16 \mathrm{~s}$ tool holding time is about $50 \%$ higher than that of the weld made with the tapered one.

4. The grain size and the volume fraction of the martensite in the heat-affected zone (HAZ) is increased as compared to the base metal. The hardness values in this region (230-270 HV0.15) indicate an increase in the martensite volume fraction in the microstructure.

5. The microstructure of the TMAZ is composed of a mixture of lath martensite and fine acicular ferrite. In addition to lath martensite, fine rods of martensite, which are less than $2 \mu \mathrm{m}$ long, are observed in the microstructure. The average hardness in the TMAZ is about 310 HV0.15.

6. As the plastic deformation during friction-stir spot welding performed with the triangular pin is more severe 
than what occurs when using the tapered pin, the grain size of the TMAZ in the weld made with the triangular pin is finer than that of the weld made with the tapered one. As a result, the hardness of the stir zone and thermo-mechanically affected zone of the weld made with the triangular pin is higher than that of the weld made with the tapered one.

\section{REFERENCES}

${ }^{1}$ H. H. Cho, H. N. Han, T. Hong, J. H. Park, Y. J. Kwon, S. H. Kim, R. J. Steel, Microstructural analysis of friction stir welded ferritic stainless steel, Materials Science \& Engineering A, 528 (2011), 2889-2894, doi:10.1016/j.msea.2010.12.061

${ }^{2}$ G. Çam, S. Mistıkoğlu, Recent Developments in Friction Stir Welding of Al-Alloys, Journal of Materials Engineering and Performance, 23 (2014), 1936-1953, doi:10.1007/s11665-014-0968-x

${ }^{3}$ G. Çam, Friction Stir Welded Structural Materials: Beyond Al-Alloys, International Materials Reviews, 56 (2011), 1-48, doi:10.1179/ 095066010X12777205875750

${ }^{4}$ W. B. Lee, Y. M. Yeon, S. B. Jung, Evaluation of the microstructure and mechanical properties of friction stir welded 6005 aluminum alloy, Materials Science and Technology, 19 (2003), 1513-1518, doi: $10.1179 / 026708303225008068$

${ }^{5}$ A. K. Lakshminarayanan, V. Balasubramanian, Assessment of fatigue life and crack growth resistance of friction stir welded AISI 409M ferritic stainless steel joints, Materials Science and Engineering A, 539 (2012), 143-153, doi:10.1016/j.msea.2012.01.071

${ }^{6}$ Y. F. Sun, H. Fujii, N. Takaki, Y. Okitsu, Microstructure and mechanical properties of mild steel joints prepared by a flat friction stir spot welding technique, Materials \& Design, 37 (2012), 384-392, doi:10.1016/j.matdes.2012.01.027.

${ }^{7}$ M. Habibnia, M. Shakeri, S. Nourouzi, M. K. Besharati Givi, Microstructural and mechanical properties of friction stir welded $5050 \mathrm{Al}$ alloy and 304 stainless steel plates, The International Journal of Advanced Manufacturing Technology, 76 (2015), 819-829, doi:10.1007/s00170-014-6306-5

${ }^{8}$ Y. Hovanski, M. L. Santella, G. J. Grant, Friction stir spot welding of hot-stamped boron steel, Scripta Materialia, 57 (2007), 873-876, doi:10.1016/j.scriptamat.2007.06.060

${ }^{9}$ Z. Feng, R. J. Steel, S. M. Packer, Friction Stir Spot Welding of Advanced High-Strength Steels - A Feasibility Study, SAE Tech. Papers, 1 (2005), 1248, doi:10.4271/2005-01-1248

${ }^{10}$ M. Azuma, S. Goutianos, N. Hansen, G. Winther, X. Huang, Effect of hardness of martensite and ferrite on void formation in dual phase steel, Materials Science and Technology, 28 (2012), 1092-1100, doi:10.1179/1743284712Y.0000000006

${ }^{11}$ B. C. Hwang, T. Y. Cao, S. Y. Shin, S. H. Kim, S. H. Lee, S. J. Kim, Effects of ferrite grain size and martensite volume fraction on dynamic deformation behaviour of $0 \cdot 15 \mathrm{C}-2 \cdot 0 \mathrm{Mn}-0 \cdot 2 \mathrm{Si}$ dual phase steels, Materials Science and Technology, 21 (2005), 967-975, doi:10.1179/174328405X47609

${ }^{12}$ M. I. Khan, M. L. Kuntz, P. Su, A. Gerlich, Y. Zhou, Resistance and friction stir spot welding of DP600: a comparative study, Science and Technology of Welding and Joining, 12 (2007), 175-182, doi:10.1179/174329307X159801

${ }^{13}$ Y. Uematsu, K. Tokaji, T. Tozaki, Y. Nakashima, Fatigue behaviour of dissimilar friction stir spot weld between A6061 and SPCC welded by a scrolled groove shoulder tool, Procedia Engineering, 2 (2010), 193-201, doi:10.1016/j.proeng.2010.03.021

${ }^{14}$ R. S. Mishra, Z. Y. Ma, Friction stir welding and processing, Materials Science and Engineering R: Reports, 50 (2005), 1-78, doi:10.1016/j.mser.2005.07.001

${ }^{15}$ R. Karthikeyan, V. Balasubramanian, Predictions of the optimized friction stir spot welding process parameters for joining AA2024 aluminum alloy using RSM, The International Journal of Advanced
Manufacturing Technology, 51 (2010), 173-183, doi:10.1007/ s00170-010-2618-2

${ }^{16}$ H. Badarinarayan, Q. Yang, S. Zhu, Effect of tool geometry on static strength of friction stir spot-welded aluminum alloy, International Journal of Machine Tools and Manufacture, 49 (2008), 142-148, doi:10.1016/j.ijmachtools.2008.09.004

${ }^{17}$ Y. H. Yin, N. Sun, T. H. North, S. S. Hu, Influence of tool design on mechanical properties of AZ31 friction stir spot welds, Science and Technology of Welding and Joining, 15 (2010), 81-86, doi:10.1179/ 136217109X12489665059384

${ }^{18}$ D. Zhang, T. Shibayanagi, Material flow during friction stir spot welding of dissimilar A12024/Al materials, Materials Science and Technology, 31 (2015), 1077-1087, doi:10.1179/1743284714Y. 0000000674

${ }^{19}$ D. Mitlin, V. Radmilovic, T. Pan, J. Chen, Z. Feng, M. L. Santella, Structure-properties relations in spot friction welded (also known as friction stir spot welded) 6111 aluminum, Materials Science and Engineering A, 441 (2006), 79-96, doi: 10.1016/j.msea.2006.06.126

${ }^{20}$ H. Badarinarayan, Y. Shi, X. Li, K. Okamoto, Effect of tool geometry on hook formation and static strength of friction stir spot welded aluminum 5754-O sheets, International Journal of Machine Tools and Manufacture, 49 (2009), 814-823, doi:10.1016/j.ijmachtools. 2009.06.001

${ }^{21}$ N. Sun, Y. H. Yin, A. P. Gerlich, T. H. North, Tool design and stir zone grain size in AZ31 friction stir spot welds, Science and Technology of Welding and Joining, 14 (2009), 747-752, doi:10.1179/ 136217109X12518083193559

${ }^{22}$ Y. H. Yin, N. Sun, T. H. North, S. S. Hu, Influence of tool design on mechanical properties of AZ31 friction stir spot welds, Science and Technology of Welding and Joining, 15 (2010), 81-86, doi:10.1179/ 136217109X12489665059384

${ }^{23}$ Y. Tozaki, Y. Uematsu, K. Tokaji, A newly developed tool without probe for friction stir spot welding and its performance, Journal of Materials Processing Technology, 210 (2010), 844-851, doi:10.1016/ j.jmatprotec.2010.01.015

${ }^{24}$ N. Sun, T. H. North, D. R. Chen, Y. H. Yin, Influences of welding parameters on mechanical properties of AZ31 friction stir spot welds, Science and Technology of Welding and Joining, 17 (2012), 304-308, doi:10.1179/1362171812Y.0000000008

${ }^{25}$ Y. Tozaki, Y. Uematsu, K. Tokaji, Effect of tool geometry on microstructure and static strength in friction stir spot welded aluminium alloys, International Journal of Machine Tools and Manufacture, 47 (2007), 2230-2236, doi:10.1016/ j.ijmachtools.2007.07.005

${ }^{26}$ C. Jonckheere, B. de Meester, C. Cassiers, M. Delhaye, A. Simar, Fracture and mechanical properties of friction stir spot welds in 6063-T6 aluminum alloy, The International Journal of Advanced Manufacturing Technology, 62 (2012), 569-575, doi:10.1007/ s00170-011-3795-3

${ }^{27}$ H. H. Cho, S. H. Kang, S. H. Kim, H. H. Oh, Microstructural evolution in friction stir welding of high-strength linepipe steel, Materials \& Design, 34 (2012), 258-267, doi:10.1016/j.matdes.2011.08.010

${ }^{28}$ A. Emamikhah, A. Abbasi, A. Atefat, M. K. Besharati Givi, Effect of tool pin profile on friction stir butt welding of high-zinc brass (CuZn40), The International Journal of Advanced Manufacturing Technology, 71 (2014), 81-90, doi:10.1007/s00170-013-5480-1

${ }^{29}$ A. Biro, B. Chenelle, D. Lados, Processing, microstructure, and residual stress effects on strength and fatigue crack growth properties in friction stir welding: a review, Metallurgical and Materials Transactions B, 43 (2012), 1622-1637, doi:10.1007/s11663-012-9716-5

${ }^{30}$ D. Bakavos, H. Chen, L. Babout, P. Prangnell, Material interactions in a novel pinless tool approach to friction stir spot welding thin aluminum sheet, Metallurgical and Materials Transactions A, 42 (2010), 1266-1282, doi:10.1007/s11661-010-0514-x

${ }^{31}$ S. Hirasawa, T. Van-Xuan, Analysis of effect of tool geometry on plastic flow during friction stir spot welding using particle method, Journal of Materials Processing Technology, 210 (2010), 1455-1463, doi:10.1016/j.jmatprotec.2010.04.003 